\title{
DA ARTE ADMINISTRADA À PRÁXIS DA FORMA
}

Robison Tramontina*

SINTESE - Este artigo tem como propósito básico explicitar a compreensão adomiana de arte e a relaçäo desta com a sociedade. Num primeiro momento aborda-se, tendo como referência a obra Dialética do esclarecimento, a inserção e cooptação da arte pela industria cultural e, posteriomente, o novo papel atribuido por Adomo à instância artística, o de uma "nova totalidade ético-veritativa" distinta da realidade social vigente.

PALAVRAS-CHAVE - Indústria cultural. Entkunstung. Mímesis. Belo natural. Racionalidade.
ABSTRACT - This article seeks to elucidate Adorno's conception of art and its relation to society. Starting from a reading of the Dialectic of enlightenment, it will be seen how art's insertion and co-opting into cultural industry gives way, in a second moment, to a new role assigned by Adorno to the artistic undertaking, namely, that of a "new ethical-truthful totality" distinguished from the current social reality.

KEY WORDS - Cultural industry. Entkunstung. Mimesis. Natural beauty. Rationality.

No acervo filosófico de Theodor Wiesengrund Adorno (1903-1969) não há nenhuma obra específica que trate de maneira pormenorizada e sistemática de questões ético-morais. O "pensamento ético adorniano" (arbitrariamente por nós assim denominado) encontra-se diluído em diversos textos, redigidos em diferentes períodos. Adorno elaboraria uma obra de filosofia moral, que formaria, juntamente com a Dialética negativa e a Teoria estética, o tríptico central de sua produção. Entretanto, devido à sua inesperada morte em 1969, seu empreendimento não pôde ser concretizado. Mas isso não significa que as questões ético-morais tenham sido preteridas no bojo da filosofia adorniana. Pelo contrário, esta temática é freqüente e perpassa, embora nem sempre de maneira explicita, vánias obras do pensador frankfurtiano.

Referenciamos para exemplificar esse argumento a Dialética do esclarecimento (1947). ${ }^{1}$ Mesmo tendo como preocupação básica a "autodestruição" do esclarecimento, ou seja, como e porque o esclarecimento, que sempre perseguiu o objetivo de livrar os homens do medo e de investi-los na posição de senhores, caiu sob o signo de uma calamidade triunfal, ${ }^{2}$ Adomo e Horkheimer, em suas reflexões e análises (principalmente no segundo excurso, intitulado Julliete ou Esclarecimento

* Mestrando do Programa de Pós-Graduação em Filosofia da PUCRS.

1 Esta obra é elaborada por Adorno em parceria com Max Horkheimer.

2 ADORNO, T., HORKHEIMER, M. Dialética do esclarecimento. Rio de Janeiro: Jorge Zahar, 1985, p. 20. 
e moral ${ }^{3}$ ), abordam a problemática ético-moral. Neste excurso, os autores pretendem, demonstrar que pelo esclarecimento se desenvolve um processo de submissão daquilo que é natural a um sujeito autocrático, que conduz ao domínio da natureza (interna e externa) e a uma falsa objetividade. Com isso, o pensamento burguês, o pensamento esclarecido, simplifica e oculta suas antinomias; de maneira especial, a antinomia do rigor moral e da absoluta amoralidade. ${ }^{4}$

Destarte, a dimensão ético-moral do pensamento adorniano está presente, ainda que subrepticiamente, em suas obras; em especial, naquelas que versam sobre a esfera cultural. No entanto, não detalharemos de forma específica, no presente artigo, o vínculo entre ética e estética na produção filosófica de Adorno. Essa ressalva introdutória tinha como pretensão apenas salientar tal conexão, considerando-se que o propósito deste trabalho é investigar como Adorno compreende a arte e a relação desta com a sociedade. A dimensão ético-moral propriamente dita que subjaz à estética adorniana será alvo de uma futura e próxima investigação. ${ }^{5}$

Dividiremos nossa investigação em dois momentos: (a) inicialmente, tendo como referência as obras $O$ fetichismo na música e a Regressão da audição (EUA1938) 6 e a Dialética do esclarecimento (Holanda-1947), ${ }^{7}$ evidenciaremos o pessimismo adorniano frente à arte no interior da indústria cultural; e (b) posteriormente, amparando-nos na obra Teoria estética (Frankfurt-1969), ${ }^{8}$ salientaremos a "nova postura" de Adorno perante a instância artística.

\section{A arte $\mathrm{e}$ a indústria cultural}

\subsection{A "ditadura da totalidade"}

No excurso intitulado "A indústria cultural: o esclarecimento como mistificação das massas", Adorno começa asseverando que os sociólogos estão equivocados ao afirmar que a perda do pressuposto religioso na legitimação do mundo cultural instaurou um caos neste âmbito da vida humana. Segundo a argumentação adorniana, essa crença é desmentida pela cultura contemporânea, pois esta confere a tudo um ar de semelhança. Todos os veículos culturais (o cinema, o rádio e as revistas) fazem parte de um só e mesmo sistema. Esta sistemática do aparato cultural é garantida pela ideologia que a sustenta.

3 Adorno, op. cit., p. 81-112.

4 Op. cit., p. 16.

5 O presente artigo, com algumas modificações, foi apresentado para a disciplina, "Conhecimento e Linguagem: Adorno e Levinas - ética e estética em diálogo e conjunção", coordenada pelo Professor Dr. Ricardo Timm de Souza. Originariamente o texto também abordava de maneira sucinta a supracitada conexão. A linha argumentativa desse texto segue o procedimento discursivo adotado por Gerson Trombetta em seu trabalho inédito intitulado Aura e mímesis.

6 Publicada em: HORKHEIMER, Max, ADORNO, Theodor W. Textos escolhidos. São Paulo: Nova Cultural, 1989, p. 78-105. (Os Pensadores)

7 Para o presente estudo utilizaremos de maneira sistemática o excurso que tem como título "A indústria cultural: o esclarecimento como mistificação das massas", p. 113-156. Segundo diversos comentadores, apesar do livro ser em parceria com Horkheimer, esse capitulo pode ser atribuido quase que exclusivamente a Adorno. A partir de agora, ao referenciá-lo, iremos considerar essa tese.

ADORNO, Theodor W. Teoria estética. Lisboa: Edições 70, s.d. 
Assim sendo, Adorno defende a noção de "totalidade longitudinal" ou seja, um conjunto de estruturas ou tendências sociais e/ou culturais de um fenômeno histórico temporal e especialmente delimitado, só que na sua forma negativa enquanto barbárie. ${ }^{9}$ Essa totalidade tem como característica básica a eliminação lenta e gradativa de todos os nichos críticos, instituindo o princípio da identidade total. Além de diagnosticar a consolidação dessa totalidade repressora e unitária, Adorno a classifica como pura falsidade, tendo em conta que a mentira é o estado permanente da sociedade atual. Os processos, relações e conflitos que se estabelecem nela nunca são verdadeiros Desse modo, Adorno é ortodoxo ao conceber a sociedade como um todo falso e ao negar-se a perscrutar resquícios de verdade, de uma forma ou de outra, que poderiam ainda existir em estado "puro" no todo indiferenciado. Essa proposição da falsidade radical da totalidade traz dificuldades à análise adorniana, considerando-se que ela não consegue abarcar a autenticidade de algumas manifestações culturais, como por exemplo, o jazz. ${ }^{10}$

Esse processo do capitalismo avançado que construiu uma "sociedade unidimensional", calcada nos pressupostos da racionalização técnica e na eliminação da não-identidade, conduz a um mundo totalmente administrado. "A inverdade do todo", apontado no loquaz euforismo de Minima Moralia (p. 57), é a expressão de que no capitalismo tardio toda forma de não-identidade é potencialmente vítima da atividade identificante do sistema. ${ }^{11}$

\section{A indústria cultural e a "des-artificação" da arte}

A expressão "indústria cultural", forjada inicialmente por Adorno, pretende dar conta da exploração racional de "bens culturais", guiada por objetivos comerciais. Ou seja, a subversão do valor de uso desses em nome de um pretenso valor de troca que eles passam a adquirir. A indústria cultural fabrica, no capitalismo avançado, elementos culturais segundo a lei da oferta e da procura, ou seja, tornaos tangiveis, palpáveis e acessíveis para que possam ser consumidos:

"A indústria cultural reflete, assim, as mesmas relações e antagonismos que 0 mundo industrial das sociedades modernas, com a diferença que, cúmplice da ideologia dominante, ela tem como papel homogeneizar e tornar inofensivos os possiveis conflitos, em particular os que poderiam provir dos focos culturais."12

Essa tendência de literalmente "consumir" a arte vai provocar um fenômeno que Adorno denominou Entkunstung, ou seja, a perda da especificidade da arte. Ele designa, de forma pejorativa, a perda do caráter propriamente estético/artístico da arte, devido à sua diluição e adaptação na totalidade no "mundo administrado". A arte se torna bem de consumo, coisa entre as coisas, enfim, valor de troca, mercadoria como outra qualquer:

9 RODRIGO, Duarte. Mímesis e racionalidade. São Paulo: Loyola, 1993, p. $157 \mathrm{seg}$.

10 JIMENEZ, M. Para ler Adorno. São Paulo: Francisco Alves, 1977, p. 88.

11 Duarte, op. cit., p. 157.

12 Jimenez, op. cit., p. 85. 
"A aparência de proximidade e imediaticidade é tão real quanto é inexorável a pressão do valor de troca. A aceitação e o acordo social harmonizam a contradição. A aparência de imediaticidade apodera-se do que na realidade não passa de um objeto de mediação do próprio valor de troca. Se a mercadoria se compõe sempre de valor de troca e do valor de uso, o mero valor de uso - aparência ilusória que os bens da cultura devem preservar, na sociedade capitalista - é substituído pelo mero valor de tro$\mathrm{ca}$, o qual, precisamente enquanto valor de troca, assume ficticiamente a função de valor de uso. [...] De tal processo de substituição social depende toda a satisfação substitutiva, toda a posterior substituição psicológica."13

É conveniente examinar melhor algumas das conseqüências estéticas da indústria cultural e da perda da especificidade artística.

A indústria cultural faz o papel de mediadora entra a objetividade e a subjetividade: entre a realidade e a razão. $\mathrm{Na}$ comparação com o conhecimento, ela teria o papel que o esquematismo kantiano ainda atribuía ao sujeito, ou seja, referir de antemão a multiplicidade sensivel aos conceitos fundamentais. Ela prepara os dados imediatos de forma a se ajustarem à razão. Para o consumidor, nada há mais para classificar que já não o tenha sido no momento da produção. As distinções da arte não dizem respeito aos seus conteúdos artísticos, mas sim ao público alvo; para todos há algo previsto. As diferenças qualitativas visam apenas à quantificação: o arrebanhamento de mais consumidores.

A indústria cultural se apresenta ao homem como um filtro na recepção do mundo: Aplainando e racionalizando os seus possiveis "choques" (conceito benjaminiano), excluindo dessa forma todo potencial crítico libertador que poderia existir nos veículos culturais.

Vemos isso de maneira explícita na análise que Adorno faz do cinema. Segundo sua concepção, a técnica chegou a tal patamar qualitativo que já não é mais possível distinguir ficção de realidade. A indústria cultural incorporou a vida:

"Ultrapassando de longe o teatro de ilusões, o filme não deixa mais à fantasia e ao pensamento dos espectadores nenhuma dimensão na qual estes possam, sem perder o fio, passear e divagar no quadro da obra filmica permanecendo, no entanto, livres do controle dos seus dados exatos, e é assim precisamente que 0 filme adestra 0 espectador entregue a ele para se identificar imediatamente com a realidade. Atualmente, a atrofia da imaginação e da espontaneidade do consumidor cultural não precisa ser reduzida a mecanismos psicológicos. Os próprios produtos - e entre eles em primeiro lugar o mais característico, o filme sonoro- paralisam essas capacidades em virtude de sua própria constituição objetiva."14

Os "choques" filmicos se dão tão velozmente e seqüencialmente que não permitem o "ócio" produtivo. Os pressupostos cognitivos para entender o filme (outros filmes e produtos culturais) já familiarizaram tanto os desempenhos exigidos pela atenção, que estes surgem como que automaticamente (memória voluntária). Assim sendo, os produtos podem gozar a certeza de que até mesmo os mais distraídos os consumirão sofregamente.

13 ADORNO, T. O fetichismo da música e a regressão da audição. p. 87

14 Adorno e Horkheimer, op. cit., p. 119. 
É nesse sentido que o lazer se aproxima do trabalho. A violência da indústria cultural não dá folga a ninguém, prende: "inevitavelmente, cada manifestação da indústria cultural reproduz as pessoas tais como as modelou a indústria em seu todo". ${ }^{15}$

Quanto à dimensão dos conteúdos da arte massificada, eles gozam de uma "finitude eterna". Essa expressão aproxima-se da mesma dinâmica já diagnosticada por Benjamin ao tratar da moda e da arte como mercadoria, e que se expressa na fórmula: "o sempre igual no sempre novo e o sempre novo no sempre igual". Devido ao seu caráter fungível, esses "conteúdos" ressurgem constantemente como "invariantes fixos", que só alteram a aparência, instaurando a lógica do "novo" a todo custo. Isso não significaria uma novidade autêntica, mas é algo, ao mesmo tempo, familiar a todos sem jamais ter ocorrido. ${ }^{16}$

Outros traços "eternos" que aparecem nos produtos de arte em geral: a seqüência de intervalos fáceis de memorizar nas músicas, o fracasso temporário do herói no filme, a briga do astro e da namorada, a regeneração da menina rica e a conquista do astro. ${ }^{17} \mathrm{O}$ uso desses clichês tornam a obra linear e previsível dando ao consumidor, que acerta na previsão, uma sensação prazeirosa, embora fugaz.

Desta maneira, as obras da indústria cultural passam a dominar as tendências, outrora indomáveis, dos detalhes. Se no romantismo, no barroco e no expressionismo, o detalhe tornara-se rebelde e veículo de protesto contra a lógica da totalidade extra- e intra-estética, na indústria cultural sua produção é administrada por especialistas e a relação entre o detalhe e a idéia abrangente perde o conteúdo dialético. Entre eles passa a não existir nem oposição nem ligação. $O$ todo estabelece uma ordem arbitrária, classificatória, mas não de conexão real ou de fundação do novo real.

\subsection{0 "estilo" da indústria cultural}

Para Adorno, a afirmação dos historiadores da arte de que o estilo perdeu a sua força criadora no Ocidente, com o capitalismo tardio, é, no mínimo, desprovida de fundamentação. O rigor do estilo de traduzir estereotipadamente tudo, mesmo aquilo que ainda não foi pensado, supera os chamados "verdadeiros estilos". O "músico de jazz que adapta Mozart ou o cineasta que adapta Balzac ou Victor Hugo", ao calcularem as caretas dos atores mediante alegria ou pavor, o "comprimento da saia da Lady" e outros detalhes, demonstram claramente que tudo deve ser previamente calculado e metrificado para que nada escape à aprovação do primeiro olhar. A linguagem assim se torna um jargão universal que se impõe tão mais eficientemente quanto mais a técnica aperfeiçoada reduz a tensão entre a obra produzida e o cotidiano. O que se busca é uma "naturalização universal", entendida enquanto nivelamento da própria linguagem.

15 Idem, p. 119.

16 OSBORNE, P. Vitónias de pequena escala, derrotas de grande escala. In: BENJAMIN, Andrew, OSBORNE, Peter. A filosofia de Walter Benjamin. Rio de Janeiro: Jorge Zahar, 1997.

17 Adorno e Horkheimer, op. cit., p. 117. 
É por isso que o estilo da indústria cultural é a negação do estilo. É transcodificar estilos em busca de teleologia. O que se perde nisso é a tensão entre o particular e o universal. Esclareçamos melhor este aspecto.

O estilo caricato forjado na indústria cultural redescobre elementos do estilo autêntico do passado. Todavia, essa redescoberta da tradição se processa enquanto dominação, pois ela extirpa a autenticidade estilística diversa, transformando todos os diferentes estilos em um só: o da industrial cultural. $\mathrm{O}$ estilo (enquanto conceito autêntico) não se define como conjunto de leis meramente estétjcas. Ele expressa a estrutura diversificada do poder social. Os grandes artistas acolheram o estilo em suas obras como possibilidade de expressão da verdade positiva, como exercício de liberdade que concedia força revigorada. O estilo autêntico se prestava a fugas e delitos; perdia-se no momento em que a integridade da obra e originalidade do autor exigisse. É comum vermos, nos clássicos, elementos que fogem ao estilo de sua época. Por outro lado, as obras da indústria cultural, adotando a padronização como caminho absoluto, reduzem o estilo a um sucedâneo de identidades. Esta harmonia estilística que, em outras palavras denota uma barbárie estática, traz em si a promessa de reconciliação com o universal, o mais inflexível dos estilos.

Nessa medida, a arte é sempre ideologia que aproxima e identifica a lógica da produção artística com a lógica do liberalismo. O liberalismo, por princípio democrático e de livre oportunidade de iniciativa para todos (sem estilo, portanto), se assemelha à ilusão da ausência de estilo na indústria cultural. No entanto, assim como no liberalismo, o caminho é livre apenas para os "competentes": "Abrir caminho para esses competentes ainda é função do mercado, que sob outros aspectos já é extremamente regulado e cuja liberdade consistia mesmo na época de seu maior brilho - para os artistas bem como para outros idiotas - em morrer de fome."18

Ao mesmo tempo que integra os artistas e seus trabalhos, a indústria cultural faz o mesmo (e de forma mais veemente) com os consumidores, a tal ponto que estes passam a desejar a ideologia que os escraviza. Esse "amor masoquista" faz o consumidor sucumbir ao que the é oferecido.

\subsection{A diversão e o prazer transferido}

O controle da indústria cultural sobre os consumidores é mediado pela diversão. O caráter de divertimento dos seus produtos veio suprir uma deficiência da arte "séria": ${ }^{19}$ a sua falsa universalidade. A arte séria recusou-se àquelas em que a seriedade soa como uma fruição prazerosa e que possuem miríades de motivos para usar como passatempo o seu tempo livre; assim, a arte "leve" se justifica enquanto má consciência social da arte séria.

18 Adomo e Horkheimer, op. cit., p. 124.

19 Utilizamos o conceito de "arte séria" para designar ạs obras que não foram apropriadas pela lógica industrial cultura e que incorporam as características da autêntica arte. 
A diversão é o ungüento do trabalho no capitalismo tardio. Ciente disso, a indústria cultural, apesar do seu poder onipotente, não impõe nada que não se funde numa necessidade produzida. Desta forma, torna-se um prolongamento do trabalho mecanizado, e isso atingiu tal grau de desenvolvimento que o consumidor já não tem condições de percebê-lo. Nesse processo, o conteúdo artístico perde o sentido. $\mathrm{O}$ que fica gravada é a seqüência, a técnica. Isso ocorre porque o conteúdo necessitaria de um esforço para ser efetivamente compreendido, o que poderia comprometer o "prazer". O público não precisa, assim, de qualquer reação. A industria cultural preenche o silêncio dos escravos sem vontade. Tudo já está encaminhado em forma de sinais didáticos que não pressupõem esforço intelectual algum. O enredo não se funda numa idéia, mas como resultado de uma situação imediatamente anterior.

Esta forma de organização, contudo, ainda pode conter resquícios "perigosos" de inteligibilidade, num ambiente onde ela é proscrita. Para combater essa antítese, funda-se a produção do absurdo e do sem-sentido: o consumidor tem de se contentar com os sustos de situações precariamente interligadas e com intensas doses de sadismo. Por exemplo: "[...] sob a gritaria do público, o protagonista é jogado para cá e para lá como um farrapo. Assim a quantidade da diversão organizada converte-se na qualidade da crueldade organizada". ${ }^{20}$

A diversão veiculada pelos mecanismos da indústria cultural geram, em verdade, um prazer constantemente oferecido mas nunca consumado. Um prazer que eles continuam a prorrogar:

"A indústria cultural não cessa de lograr seus consumidores quanto àquilo que está continuamente a lhes prometer. A promissória sobre o prazer, emitida pelo enredo e pela encenação, é prorrogada indefinidamente: maldosamente a promessa a que afinal se reduz o espetáculo significa que jamais se chega ao fim do cardápio."21

Esse prazer protelado vai significar, em última análise, uma apologia do cotidiano de que se pretendia escapar. Pode-se compreender melhor isso se temat1zarmos a dimensão erótica desse processo, que acaba se traduzindo em repressão: o prazer não mediatizado dos produtos artísticos ("o busto do suéter ou o torso nu do desportista") apenas excita preliminarmente uma superfície de excitação não sublimada, completamente indefesa frente ao hábito da renúncia. Assim, a negação cotidiana do prazer vê seu prolongamento, em tons mais sutis, nos momentos de lazer.

A indústria cultural oferece e, ao mesmo tempo, priva. O princípio é que as necessidades que são apresentadas podem ser supridas. Ela faz entender que este duplo movimento do oferecer e do privar constitui a verdadeira satisfação e que 0 paraíso é mesmo o cotidiano de que se quer escapar. Esse é o processo que Adorno chama de "espiritualização forçada da diversão", que a linha entre os ideais tomando lugar dos bens superiores e os expulsando da mesma. Assim, o divertimento significaria:

20 Adorno e Horkheimer, op. cit., p. 129.

21 Idem, p. 134. 
“[...] não ter que pensar nisso, esquecer o sofrimento até mesmo onde ele é mostrado. A impotência é a sua própria base. É na verdade uma fuga, mas não como se afirma, uma fuga da realidade ruim, mas da última idéia de resistência que esta realidade deixa subsistir. A liberação prometida pela diversão é a liberação do pensamento como negação."22

Para Adorno, ao contrário, o prazer é essencialmente mediatizável e preliminarmente ascético. Para explicitar melhor essa idéia, ele retoma a reflexão platônica sobre a música ideal para um projeto educacional. ${ }^{23} \mathrm{O}$ que a música proíbe ao ateniense é exatamente o traço prazeroso, a superficialidade e a consciência diferenciada. São exatamente esses elementos censuráveis de que a música ocidental se apropriou.

Se, como Adorno e Horkheimer dizem na Dialética do esclarecimento, a razão sucumbiu a um processo alienante e reificador (instrumental) devido à preponderância de seus elementos destrutivos em detrimento aos esclarecedores, na arte, de um modo geral, e na música especificamente, o fenômeno é análogo. A subjetividade, o prazer e a profanação - elementos seguramente anti-mitológicos - se convertem em conspiradores contra a liberdade pela qual, outrora, lutaram. O que se instaura, enfim, é a ditadura do sucesso comercial. De um outro lado, o consumidor, desimpedido da obrigação rígida, é relegado ao oposto radical: um mero consumidor passivo.

O que fica seriamente comprometido nesse processo é a unidade estética da obra: um corpo de prazer e dor, profanação e disciplina, profundidade e superficialidade. Isolados, esses elementos degeneram o espírito, limitando-o: "Ouem a eles se entrega é tão pérfido quanto os antigos noéticos em seus ataques ao seu prazer sensual". 24

Uma arte que se pretende "séria" não pode abrir mão de seus traços ascéticos. O que ela tem apresentado, com a modernização de sua técnica, é uma falsa felicidade, uma ilusão. O que nos vêm totalmente envolvido em categorias de prazer não pode ser verdadeiramente degustados. A autêntica promessa de felicidade só encontra condições de possibilidade onde cessa a mera aparência, o que é puro prazer.

\section{A arte como a totalidade e a práxis da forma}

Para Adorno, a capitulação da arte frente a racionalidade tecnológica, culmina na adesão dessa à uma totalidade que a controla e mutila seus traços estéticos constitutivos e como ideologia legitimadora. Contra essa situação, contra esse "mundo administrado", pouco pode-se fazer. Esse pessimismo é uma constante na produção filosófica de Adorno nas décadas de 40 e 50 . No entanto, na obra Teoria estética há uma sensível relativização dessa posição. Como procuraremos demonstrar, nela há um resguardo da arte como totalidade específica, fundada na

22 Adorno e Horkheimer, op. cit., p. 135.

23 Pode-se, para melhor esclarecimento sobre esse aspecto, consultar a obra $O$ fetichismo da música $e$ a regressão da audição, p. $81 \mathrm{seg}$.

24 Adorno, op. cit., p. 32. 
capacidade de garantir uma mediação crítica entre um estado de coisas insólito e desesperador, tanto material como espiritualmente e a construção de um locus crítico, uma filosofia que reserva lugar à esperança.

Essa concepção encontra sua justificativa na medida que se reconhece na arte uma segunda natureza. Uma natureza que insiste em fugir do uso instrumental, totalizador típico das sociedades de capitalismo avançado e que, por isso mesmo, funda uma nova práxis. A práxis da arte não é seu efeito, mas é inerente ao seu processo de individuação constituindo o seu conteúdo de verdade.

\subsection{O caráter aporético da obra de arte}

Anteriormente à emancipação do sujeito (entendida enquanto Aufklärung25), a arte já possuía um caráter social manifesto. Entretanto, este permanecia reduzido ao seu uso cultual/religioso. A possibilidade só se concretizou devido à constituição histórica da liberdade burguesa. No entanto, esse novo quadro jogou a arte num paradoxo: à medida que conquista a sua autonomia, a sociedade burguesa "[...] integrou a arte mais completamente do que alguma vez o fizera uma sociedade anterior", ${ }^{26}$ exteriorizando cada vez mais a dimensão social existente nela. Esse fator social na obra de arte, visto não dialeticamente, nasce com e produz 0 seu emburguesamento. É necessário, então que percebamos os contornos dialéticos que assume este "social" no contexto artístico.

A forma artística parte, indubitavelmente, de um pressuposto de experiência, para, em seguida, constituir-se como arte. Desde já, estas experiências são realistas, segundo o "estado puramente estético", antes de todo o conteúdo: ela proporciona um espaço para a alteridade.

"Se é percebida de modo estritamente estético, não o é, portanto, de uma maneira correta. Só quando se sente ao mesmo tempo o Outro da arte como um dos primeiros estratos da experiência é que esta pode sublimar-se e resolver a implicação na matéria, sem que o ser-para-si da arte se transforme em alguma coisa de indiferente. A arte é para si e não o é; subtrai-lhe a sua autonomia, mas não o que the é heterogêneo."27

Todavia, o caráter social autêntico da arte não se reduz apenas a um produto da dialética entre forças produtivas e relações de produção (o que seria limitá-la ao domínio instrumental), ou pela inspiração social do seu conteúdo temático, mas, "torna-se antes social através da posição antagonista que adota perante a sociedade e só ocupa tal posição enquanto arte autônoma". ${ }^{28}$

Critica a sociedade pela sua própria existência enquanto pura inutilidade em si mesma. Sendo pura em si mesma, completamente estruturada segundo a sua lei imanente, ela afronta uma sociedade baseada na troca total, onde tudo existe enquanto meio, ser-para-outros: é uma negação determinada de uma sociedade determinada.

Conformamos este conceito ao trabalhado por Guido A. de Almeida em Nota Preliminar da tradução brasileira da obra Dialética do esclarecimento: "[...] processo pelo qual, ao longo da história, os homens se libertam das potências míticas da natureza, ou seja, o processo de racionalização que prossegue na filosofia e na ciência" (p. 8).

Adorno, op. cit., p. 253. 
Isso funda uma profunda alteridade na sua constituição mesma. A condição de possibilidade de existência desse caráter é consoante à existência, no mundo dos entes, de fragmentos da mesma alteridade. A síntese operada por ela não é, desta forma, imposta. A arte participa do que lhe é contrário. Segundo Adorno, essa autoconsciência "motivou a viragem crítico-cultural da arte, que se desembaraçou da ilusão do seu ser puramente espiritual".

Denominou-se essa lógica de "lógica do terceiro incluso", ${ }^{29}$ para diferenciá-lo do princípio da identidade, ${ }^{30}$ muito premente na razão instrumental:

"A lei da arte é regida pela coerência negativa, onde tudo pode ser simultaneamente falso, verdadeiro ou não figurar através dessas categorias, algo próximo daquilo que a psicanálise estética denominou de coerência inconsciente. A lógica da arte é a lógica do terceiro incluso, da coerência negativa típica da imaginação criadora e que desinveste a obra dos vícios da lógica administrativa do mundo. [...] Se a lógica da arte é contradição, a contradição da arte é a lógica estética." ${ }^{31}$

A força social em relação produz a arte, que dela se afasta, fugindo dos seus sortilégios. Isso lhe permite participar na Aufklärung e, ao mesmo tempo, the dá um caráter de realidade que se antepõe, enquanto resposta à forma interrogativa que lhe vem do exterior. É da natureza da arte captar o que não está resolvido na sociedade. A sua própria tensão é significativa na relação com a tensão externa. Essa hipótese encontra seu fundamento no fetichismo que a arte é portadora e na dialética imanente entre racionalidade e mímesis.

O conteúdo de verdade de uma obra encontra a sua "condição" no seu caráter fetichista. Adorno entende aqui o fetichismo como pura negação do ser-paraoutro, como qualidade daquilo que é finito em si mesmo. Esse fetichismo teria nascido com o uso cultural da arte, mas nem por isso teriam assumido um valor negativo - o que é muito diferente do fetichismo da mercadoria. O fetichismo da obra de arte deve ser entendido como um momento de absoluta cegueira, de total incoerência e sublime fuga. A tentativa de controlar esse momento da arte significa impor tentáculos instrumentais ao que, profundamente, foge disso. Seria uma tentativa de denunciar e fazer enxergar uma cegueira sem a qual a arte não é ela própria e a isso chamamos auto-negação.

Por conseqüência, temos uma dura crítica ao que se convencionou chamar de "arte engajada" - de cujo modelo Brecht teria sido o artista mais demonstrativo principalmente quanto à idéia de transformar a arte num veículo de conscientização, bem como ao uso mercadológico - burguês da arte: há uma aguda contradição que perpassa essas formas.

Em suma, em relação a seu fetichismo:

29 MORENO, João Ricardo. Adomo e a estética do terceiro incluso. Revista de Cultura Vozes, ensaios e expressões. Petrópolis: Vozes, ano 86, v. 88, n. 5, p. 72-80, set.-out. 1992.

30 Por "princípio da identidade" nos referimos ao seu conceito clássico, ou seja, "o que é, é, e o que não é, não é". Numa representação algébrica teríamos: "Se A = B e B \# C, então, A \# C". Na estética esse princípio é francamente subvertido, pois, no seu contexto, nada é apenas o que é, tudo é também o que não é.

31 Moreno, op. cit., p. 73-74. 
“[...] elas não podem nem desembaraçar-se dele, nem negá-lo; [...] As obras de arte, que procuram desembaraçar-se do feitichismo por um empenhamento politico verdadeiramente muito problemático, emaranham-se na falsa consciência por uma simplificação inevitável e em vão enaltecida. Na práxis a curto prazo, a qual se devotam cegamente, prolongam-se a sua própria cegueira." 32

Aparentemente, Adorno cai num objetualismo panteísta, ao atribuir essa quase autonomia metafísica à arte como tal e seu caráter eminentemente fugidio. Entretanto, essa desconfiança desfaz-se se levarmos em consideração que a constituição da arte emana de uma Segunda natureza, de uma totalidade diferente da dos outros processos sociais. Aliás, muito pelo contrário, a intenção de Adorno, segundo ele próprio, é fazer uma interpretação materialista da arte e isso só pode se fundamentar no caráter aporético da sua constituição social.

Até agora explicitamos que o caráter social da arte não deve ser procurado no âmbito de sua recepção, pois este é um fenômeno. extremamente mediatizado (enquanto reação humana) e pode acabar por não se referir exatamente à coisa. "A recepção quase sempre edulcora aquilo em que a arte era negação determinada da sociedade." 33 O seu autêntico caráter social deve então ser procurado no momento da sua individuação, da sua produção. Arte e sociedade convergem no conteúdo da arte. Ao "entrar" na arte, a sociedade "perde-se", transubstancia-se, ao passo que a arte se torna busca de socialização. Assim, o que é efetivamente social na obra de arte, paradoxalmente, é o seu movimento imanente contra a sociedade. Não como uma decisão exteriorizada, destemida e manifesta, como o "camarada", no portão da fábrica, de megafone em punho, convocando os "proletários" para a greve, mas simplesmente como fugidia, indomada.

"A forma age como um imã que organiza os elementos da empiria de um modo que os torna estranhos ao contexto da sua existência extra-estética, e só assim eles podem assenhorar-se da sua essência extra-estética. [...] O seu gestus histórico repele de si a realidade empirica de que, no entanto, são uma parte das obras de arte enquanto coisas. [...] O seu encantamento é desencantamento." ${ }^{34}$

O que exprime esta última citação não é mais senão o caráter aporético com que convive a obra de arte, sob o ponto de vista da sua relação com a sociedade. A arte assume um caráter mediador que subverte as suas determinações sociais. Isso se torna confuso se não levarmos em conta o jogo dialético entre mímesis e racionalidade que a perpassa.

\subsection{Mímesis e racionalidade}

O jogo dialético entre mímesis e racionalidade representa a própria idéia de mediação presente na obra de arte. Esses conceitos só podem ser entendidos dentro de um contexto onde o que está posto em causa é o domínio da natureza.

32 Adorno, op. cit., p. 256.

33 Idem, p. 256-257.

34 Idem, p. 254-255. 
Como vimos, a essência aporética da arte pressupõe que o domínio estético preserva traços sociais, ou seja, é, de alguma forma domínio afetivo, econômico e real da natureza, mas, ao mesmo tempo, ele se situa num mirante crítico com relação a este último.

Necessariamente fica expresso que o material artístico constitui uma segunda natureza, uma natureza que fala (mímesis) e, ao seu domínio, um caráter depurado de instrumentalidade, uma terapia da própria racionalidade como tal. É essa relação que, ao mesmo tempo, aproxima e afasta o artista do cientista. Na medida em que o primeiro se dispõe a experimentar os elementos, de dominá-los racionalmente, concedendo à arte a força propulsora de sua autonomia, imediatamente este domínio se converte em dívida a ser paga por um "mundo", perante o qual é absolutamente crítica. Como o próprio Adorno nos fala, esse é o "pecado original" da arte. $\mathrm{O}$ conceito de experimento poderia significar uma ponte entre o domínio estético e o científico da natureza. Se a arte fala por si só, na medida de sua individuação, o momento do experimento científico também equivale a uma concessão de voz ao objeto.

O momento, na obra de arte, em que a natureza toma a palavra, é denominado momento mimético: uma atitude de precaução contra o domínio unilateral dela própria. Desta forma, os marcos científicos como a unilateralidade do tempo, espaço e causalidade, no âmbito artístico são falsificados: ela os comenda aleatoriamente. "Se aquelas formas são, na existência externa, as balizas do domínio da natureza, na arte, por sua vez, elas são denominadas, controla-se-as pela liberdade. Através do domínio do dominante a arte revida interiormente o domínio da natureza." 35

Nesse processo, a mímesis se traduz em uma espiritualização positiva da obra, como um corretivo do domínio instrumental da natureza. Essa é a grande revolução no conceito de mímesis de Adorno, pois o aproxima da idéia de emancipação tanto da natureza como da racionalidade (enquanto depuração dos traços de domínio do próprio homem que esta carrega).

\footnotetext{
"Que ela, algo de mimético, seja possível no seio da racionalidade e se sirva dos seus meios, é uma reação à má racionalidade do mundo racional enquanto administrado. Pois, o objetivo de toda a racionalidade, da totalidade dos meios que dominam a natureza, seria o que já não é meio, por conseguinte, algo de não-racional. Precisamente, esta irracionalidade oculta e nega a sociedade capitalista e, em contrapartida, a arte representa a verdade numa dupla acepção: conserva a imagem do seu objetivo obstruida pela racionalidade e convence $o$ estado de coisas existente da sua irracionalidade, de sua absurdidade. $\mathrm{O}$ abandono da ilusão de uma apreensão imediata do espírito, que regressa insaciavelmente e de modo intermitente na história da humanidade, transforma-se em interdito de a memória se voltar imediatamente, através da arte, para a natureza." 36
}

35 Idem, p. 207.

36 Idem, p. 68-69. 
É importante, para compreendermos a dialética entre mímesis e racionalidade, consideramos diferença entre mímesis e mimetismo (Mimikry). "[...] este último significa tornar-se igual à natureza como um meio de se proteger contra a sua hiperpotência". ${ }^{37}$

A mímesis extrapola essa dimensão irracional da dominação. Ela só é possivel quando a natureza é "intencionalmente", racionalmente imitada, como uma "práxis" do seu domínio, no trabalho social do artista. Desta forma, mímesis e racionalidade se compatibilizam dialeticamente e de forma plena no interior da obra de arte. A força expressiva da arte, que a diferencia do difuso, do caótico, é o seu fundamento de realidade e representa os seus traços mimético e racional concomitantes, que darão origem à aporia fundamental: igualar-se à realidade para resistir-lhe simultaneamente.

Assim, a mímesis impede um duplo suicídio da arte, ou seja: primeiro, o seu "afogamento" no princípio do prazer. Isso serve de crítica tanto ao seu uso ideológico, já apreciado com o nome de Éntkunstung, quanto a uma tendência da arte avançada a qual Adorno denominou de tabu mimético, da qual o surrealismo é a expressão fundamental; segundo, e que constitui o outro lado desta moeda, é a tendência da construção da obra, a idéia de conceder-lhe uma função.

A arte autêntica fica assim caraterizada por uma surpreendente dialética entre expressão e construção, que jamais pode ser interrompida, o que designa uma tensão perene entre seu momento racional e mimético:

"A aporia da arte, entre a regressão à magia literal ou transferência do impulso mimético para a racionalidade coisificante, prescreve-lhe a sua lei de movimento; tal aporia não pode remover-se. A profundidade do processo, que é cada obra de arte, é posta a descoberto pela irreconciliação desses momentos: é preciso acrescentá-la à idéia da arte como imagem de reconciliação. [...] A arte é racionalidade, que critica esta sem lhe subtrair; não é algo de pré-racional ou irracional, como se estivesse antecipadamente condenada à inverdade perante o entrelaçamento de qualquer atividade humana na totalidade social." 38

Esse é o critério que permite a Adorno citar Schönberg, Paul Klee e Pablo Picasso como arautos da verdadeira arte na contemporaneidade.

Tudo o que foi exposto nessa seção configura o caráter enigmático da arte, que, ininterruptamente, a afasta da sua utilidade, da sua função, da sua razão de ser, ao passo em que a aproxima de sua substância ética. Só compreenderemos essa constelação de idéias se nos reportarmos a uma outra, a originária, o fundamento do poder expressivo da arte: o belo natural.

\subsection{O belo natural como fundamento da mímesis}

Adorno acredita que, desde Schelling, o interesse estético passou a deslocarse para as obras de arte, mais especificamente para o belo artístico, sendo que 0 belo natural dificilmente tem aparecido como interesse temático. Com Hegel, ele foi realmente superado por algo "superior", tendo sido recalcado. Essa compreen-

37 Baseamos essa interpretação na reflexão de Duarte (op. cit., p. 136 seg.).

38 Adomo, op. cit. p. 69-70. 
são, no entanto, precisa ser revista. Se sua tematização dá impressão de algo ultrapassado, arcaico, monótono, a reflexão sobre o belo natural é inalienável à arte: ao confiná-lo para lá da estética, recai-se todavia, novamente, em uma sua condição.

Com a idéia do belo natural aconteceu um processo semelhante à gênese da racionalidade instrumental moderna. ${ }^{39}$ Seu sentido primeiro foi representar uma força do domínio estético sobre o poder hercúleo da natureza, como condição da liberdade do sujeito autônomo. No entanto, a morte sob o peso da natureza, da qual procurava escapar, tomou-se o seu destino ao fundir-se no mundo administrado, assumindo uma função homeostásica e hedonista.

"A verdade de tal liberdade para si é, porém, ao mesmo tempo inverdade: servidão para outro. Eis porque à propensão para 0 belo natural, não obstante o progresso incomensurável na concepção da arte como algo espiritual, que ela possibilitou, tão pouco falta o momento destruidor, como também ao conceito de dignidade relativamente à natureza." 40

Sendo assim, arte e natureza, enquanto dimensões antitéticas, então inextricavelmente ligadas uma à outra: a natureza, enquanto dado imediato, necessita de mediação de algo para chegar à experiência de um mundo objetivado; a arte, por outro lado, enquanto pura mediação e desejo de socialização, não pode prescindir da natureza, que representa a sua imediatidade: "A arte torna-se, portanto, representante da natureza no mundo dos artefactos". 41

O belo natural, com o desenvolvimento das forças produtivas, foi sendo gradativamente substituído pelo belo artístico e mediando-se nele, já que a experiência direta da natureza e do seu belo é ambígua, pois lhe falta muito em mediação. A sua força e sua fraqueza habita no fato de representa uma lacuna no que se entende por domínio da natureza:

"A sua força, porque ela relembra o estado de não-dominação, que provavelmente nunca existiu; a sua fraqueza, porque ela se dissolve precisamente assim no amorfo de onde se elevou o gênio que só podia caber em sorte àquela idéia de liberdade realizada num estado de não-dominação. $\mathrm{A}$ anamnese da liberdade no belo natural induz em erro porque espera a liberdade da servidão antiga. $\mathrm{O}$ belo natural é o mito transposto para a imaginação e, talvez por isso, liquidado." 42

A obra de arte, enquanto mediador desse belo, é sábia pois não representa um imediato retorno à natureza mítica, já que se encontra permeada de racionalidade. Nesse sentido, a arte representa a natureza mediante a sua eliminação enquanto face ${ }^{43}$. Por outro lado, a arte como pura mediação, sem a noção do belo natural, representaria uma promessa de emancipação enquanto reconciliação com a natureza num "para além" e não como mero rememorar do "paraíso perdido".

39 Da forma como é tratada na Dialética do esclarecimento.

40 Adomo, op. cit., p. 78.

41 Duarte, op. cit., p. 144.

42 Adomo, op. cit., p. 82.

43 Essa afirmação, em última análise, se converte em aguda crítica ao movimento naturalista da arte: segundo Adorno, só falaciosamente a arte natural aproxima-se da natureza pois, tal como na indústria, a reduz à matéria-prima. 
Chegamos, assim, ao ponto nevrálgico da situação mimética da arte: seu ambiente é o momento em que a natureza, ou mais especificamente, o seu belo, "ergue o olhar" e recupera a sua força. O que fica designado aqui é uma dialética fundamental entre a objetividade e a subjetividade comportada na experiência artistica e sua mútua interdependência:

"Belo, na natureza, é o que aparece como algo mais do que o que existe literalmente no seu lugar. Sem receptividade, não existiria uma tal expressão objetiva, mas ela não se reduz ao sujeito; o belo natural aponta para o primado do objeto na experiência artística subjetiva. Ele é percebido ao mesmo tempo como algo de compulsivamente obrigatório e como incompreensivel, que espera interrogativamente a sua resolução. Poucas coisas se transferiram tão perfeitamente do belo natural para as obras de arte como este duplo caráter. Sob este aspecto, a arte é, em vez de imitação da natureza, uma imitação do belo natural." 44

E esse belo não é concebido como uma idéia estática, idêntica em todos os objetos da natureza, pelo contrário, ele representa exatamente o que é peculiar, diferente, "näo-idêntico" - "etico" - nas coisas. Existe e encontra seu sentido na fuga da identidade violenta dos entes.

\section{Referências bibliográficas}

ADORNO, Theodor W. Sociologia. São Paulo: Ática, 1986. 207 p.

Teoria estética. Lisboa: Ediçöes 70. São Paulo: Martins Fontes, s.d.. 404 p.

ADORNO, Theodor W., HORKHEIMER, Max. Dialética do esclarecimento. Rio de Janeiro: Jorge Zahar, 1985. $254 \mathrm{p}$.

BENJAMIN, Walter. A obra de arte na época de suas técnicas da reprodução. São Paulo: Abril, 1975, p. 9-34. (Os Pensadores)

— Obras Escolhidas III: Charles Baudelaire - um línco no auge do capitalismo. São Paulo: Brasiliense, 1991. $272 \mathrm{p}$.

DUARTE, Rodrigo A. de Paiva. Mímesis e racionalidade. São Paulo: Loyola, 1993.

JAMESON, Frederic. Marxismo e forma, São Paulo: Hucitec, 1985. 331 p.

JIMENEZ, Marc. Para ler Adomo. Rio de Janeiro: Francisco Alves, 1977. 215 p.

MARCUSE, Herbert. A dimensão estética. Lisboa: Edições 70. São Paulo: Martins Fontes, 1986.93 p.

MERQUIOR, José Guilherme. Arte e sociedade em Adomo, Marcuse e Benjamin. Rio de Janeiro: Tempo Brasileiro, 1969. 311 p.

MORENO, João Ricardo. Adomo e a estética do terceiro incluso. Revista de Cultura Vozes, ensaios e expressões. Petrópolis: Vozes, v. 88, n. 5, p. 72-80, set.-out. 1992.

44 Adorno, op. cit., p. 87. 